\section{Burden of cancer mortality and differences attributable to demographic aging and risk factors in Argentina, 1986-2011}

\author{
Carga de mortalidad por cáncer y diferencias \\ atribuibles al envejecimiento poblacional y \\ factores de riesgo en Argentina, 1986-2011
}

\section{Carga de mortalidade por câncer e diferenças atribuíveis ao envelhecimento populacional e fatores de risco na Argentina, 1986-2011}

Sonia Alejandra Pou 1

Natalia Tumas 2

Julia Becaria Coquet 1

Camila Niclis 1

María Dolores Román 1

María del Pilar Díaz 1

doi: 10.1590/0102-311X00016616

\begin{abstract}
The world faces an aging population that implies a large number of people affected with chronic diseases. Argentina has reached an advanced stage of demographic transition and presents a comparatively high rate of cancer mortality within Latin America. The objectives of this study were to examine cancer mortality trends in the province of Córdoba, Argentina, between 1986 and 2011, and to analyze the differences attributable to risk variations and demographic changes. Longitudinal series of age-standardized mortality rates for overall, breast and prostate cancers were modeled by Joinpoint regression to estimate the annual percent change. The Bashir er Estève method was used to split crude mortality rate variation into three components: mortality risk, population age structure and population size. A decreasing cancer agestandardized mortality rates trend was observed (1986-2011 annual percent change: -1.4, 95\%CI: - 1.6, - 1.2 in men; -0.8, 95\%CI: - 1.0, -0.6 in women), with a significant shift in 1996. There were positive crude mortality rate net changes for overall female cancer, breast and prostate cancers, which were primarily attributable to demographic changes. Inversely, overall male cancer crude mortality rate showed a 9.15\% decrease, mostly due to mortality risk. Despite favorable age-standardized mortality rates trends, the influence of population aging reinforces the challenge to control cancer in populations with an increasingly aged demographic structure.
\end{abstract}

Neoplasms; Cost of Illness; Demographic Aging

\section{Correspondence}

M. P. Díaz

Facultad de Ciencias Médicas, Instituto de Investigaciones en Ciencias de la Salud, Universidad Nacional de Córdoba. Av. Enrique Barros y Enfermera Gordillo, Córdoba / Córdoba 5000, Argentina.

pdiaz@fcm.unc.edu.ar

1 Instituto de Investigaciones en Ciencias de la Salud, Universidad Nacional de Córdoba, Córdoba, Argentina. 2 Centro de Investigaciones y Estudios sobre Cultura y Sociedad, Universidad Nacional de Córdoba, Córdoba, Argentina. 


\section{Introduction}

In recent decades, all regions of the world have been experiencing a demographic transition (i.e. changing patterns of mortality, fertility and life expectancy) ${ }^{1}$ along with epidemiological changes characterized by the emerging importance of chronic diseases 2 . The worldwide increase in the elderly population entails a large number of people afflicted with such diseases ${ }^{3}$. Globally, noncommunicable diseases (NCD) kill 38 million people each year, and cancer accounts for $22 \%$ of all NCD deaths 4. In Argentina, cancer was the second most important cause of death (18.5\% of total mortality) in 20135.

The demographic aging phenomenon is driving the worldwide epidemic of NCD 6 and is taking place alongside other broad social trends that will affect the lives of elderly people 2. Demographers seek explanations for mortality transition, placing emphases on the role of modern medicine, the rise in living standards and better nutrition, and behavioral and social change 7 . In addition, the so-called health transition - focused on the socio-cultural and behavioral determinants of health interacting with the provision of health services 8 - provide an integrative framework to identify factors underlying mortality trends.

The study of cancer mortality trends enables an historical path analysis of the risk of death from cancer. The estimation of age-standardized mortality rates, traditionally used for this purpose, removes the potential distortion on observed variations in mortality risk that arises from factors including the age and gender structure of the population. Therefore, since the reference population is a common standard in estimation of age-standardized mortality rate, it is only possible to evaluate differences in mortality data due to risk but not those attributed to demographic factors 9 . These factors are highly relevant given the new context of demographic aging and its potential impact on the development of rational health policies. Therefore, Bashir \& Estève 10 proposed a method for partitioning the variation in mortality data between two chronological dates, in terms of demographic variation (population size and population age structure) and differences attributed to changes in risk.

In Argentina, $10.2 \%$ of the population is 64 years or older 11. In Córdoba (the second most populous province of Argentina with 3,308,876 inhabitants), this age group presents a similar percentage (11.2\%), and cancer is a main cause of mortality. Prostate and breast cancers are included among the most frequent cancer types by sex 12 .

The aims of this study were to examine changes in cancer mortality rates in the population of Córdoba between 1986 and 2011, and to analyze the differences attributable to risk variations and demographic changes (in population size and age structure). Since the increase in life expectancy is sex differential 13, rates for overall cancer (female or male) and two sex-specific malignant tumors, breast and prostate, were selected for the analysis.

\section{Methods}

\section{Study design and data}

A retrospective trend analysis of cancer mortality was performed in Córdoba province of Argentina through the period from 1986 to 2011. The number of deaths from cancer was obtained from official sources (Córdoba Ministry of Health and Argentinian Ministry of Health) for Córdoba province. Population data was taken from the database of the National Institute of Statistics and Censuses (INDEC), using the population censuses of 1980, 1991, 2001 and 2010. In inter-census periods, population size was estimated by exponential interpolation.

Estimations were used for overall (codes 140-208 and C00-C97 from the 9th and 10th revisions of the International Classification of Diseases - ICD, respectively), breast (ICD-9 174, ICD-10 C50) and prostate (ICD-9 185, ICD-10 C61) crude mortality rates (CMR) and age-standardized cancer mortality rates were estimated. Age-standardized cancer mortality rates per 100,000 people/year (world standard population) was estimated by direct methods using Stata 12.0 software (StataCorp LP, College Station, USA). 


\section{Statistical analysis}

Longitudinal series of age-standardized cancer mortality rates (1986-2011) were modeled using version 4.2.0.2 of the Joinpoint Regression Program from June 2015 (Statistical Research and Application Branch, US National Cancer Institute). Joinpoint analysis was used to obtain the estimated annual percent change and to identify the calendar years in which statistically significant changes in trends occur. This analysis makes it possible to find the number of significant Joinpoints by performing several permutation tests (Monte Carlo method), each of which has a correct significance level asymptotically 14 .

The Bashir \& Estève 10 method was used in order to separate the crude mortality rate temporal variation into three components: differences due to changing risk of dying from cancer and those due to age and size population variations. It assumes two groups: the baseline (or reference) group and the comparison group. The number of death cases is given for both groups, aggregated by age-groups (5-year groups). The observed difference in the total number of deaths between both groups can then be split into: deaths due to changes in population size, deaths due to changes in population structure (age distribution) and deaths attributable to changes in the risk of dying due to the disease itself. Crude rates (per 100,000 people) have to first be computed, then the difference in the crude rates from both groups have to be divided between those that are due to risk and those due to population structure, using the expression:

$\frac{S_{2}-S_{1}}{S_{1}}=\frac{S_{3}-S_{1}}{S_{1}}+\frac{S_{2}-S_{3}}{S_{1}}$,

where $S_{1}$ and $S_{2}$ are the crude rates for the baseline and comparison group respectively, and $S_{3}$ is an intermediate rate obtained for the baseline group but using the comparison group as the reference population. Thus, $\left(S_{2}-S_{1}\right) / S_{1}$ represents the proportional change between the observed rates in two groups, which is then divided into the proportional change due to population structure $\left(S_{3}-S_{1}\right) / S_{1}$ and the proportional change due to differences in risk $\left(S_{2}-S_{3}\right) / S_{1} 10$.

The RiskDiff web-based application (Registre de Càncer de Catalunya, 2009-2014) was implemented to perform this analysis 9 . The year 1986 was used as a baseline and 2011 as a comparison year, along with other intermediate temporal segments (1986-1991; 1991-1996; 1996-2001; 2001-2011). More detail about the algebraic formulation of this can be found in Bashir \& Estève 10.

This study was carried out in compliance with the ethical principles contained in the Helsinki Declaration of the World Medical Association. No ethical approval was required as anonymous records and datasets existing in the public domain were involved in this research.

\section{Results}

Between 1986 and 2011, 129,599 deaths were attributed to cancer in Córdoba province (55\% males and 45\% females); in 2011, there were 171.1 (age-standardized mortality rates: 132.2) and 146.3 (age-standardized mortality rates: 90.3) deaths per 100,000 persons-year, in the male and female populations, respectively. In the same year, 20.7 deaths per 100,000 (age-standardized mortality rates: 13.8) were due to prostate cancer and 31.5 (age-standardized mortality rates: 20.4) to breast cancer (Table 1).

Table 1 shows results from Joinpoint regression analysis. Figure 1 and 2 illustrate the age-standardized mortality rates trends for the years 1986 to 2011 from a selected model with 1 joinpoint. In 1986 and 2011, estimated mortality rates (crude mortality rates and age-standardized mortality rates) for overall cancer were higher in men than in women. However, cancer age-standardized mortality rates trends (1986-2011) decreased significantly in both sexes, mainly in men (annual percent change: -1.4 vs. -0.8 in females), with a significant inflection point in 1996 (Table 1, Figure 1). Also, agestandardized mortality rates of breast and prostate cancers had similar trends, except for the 19861996 period, which showed an annual increase of $1.4 \%$ in breast cancer age-standardized mortality rate (Table 1, Figure 2). 
Crude and age-standardized cancer mortality rates by sex and estimated annual percent change from joinpoint regression analysis. Córdoba province, Argentina, 1986-2011.

\begin{tabular}{|c|c|c|c|c|c|c|c|c|c|}
\hline & \multicolumn{2}{|c|}{$\begin{array}{c}\text { Crude } \\
\text { mortality } \\
\text { rate } \\
\text { (per } 100,000)\end{array}$} & \multicolumn{2}{|c|}{$\begin{array}{c}\text { Age } \\
\text { standardized } \\
\text { cancer } \\
\text { mortality rates } \\
\text { (per 100,000) }\end{array}$} & \multirow{2}{*}{$\begin{array}{c}\text { 1986-2011 } \\
\text { annual percent } \\
\text { change of age- } \\
\text { standardized } \\
\text { cancer } \\
\text { mortality rates } \\
\text { Annual percent } \\
\text { change }(95 \% \mathrm{Cl})\end{array}$} & \multicolumn{2}{|c|}{ Trend 1} & \multicolumn{2}{|c|}{ Trend 2} \\
\hline & 1986 & 2011 & 1986 & 2011 & & Years & $\begin{array}{l}\text { Annual percent } \\
\text { change }(95 \% \mathrm{Cl})\end{array}$ & Years & $\begin{array}{l}\text { Annual percent } \\
\text { change }(95 \% \mathrm{CI})\end{array}$ \\
\hline \multicolumn{10}{|l|}{ Male population } \\
\hline $\begin{array}{l}\text { Overall } \\
\text { cancer }\end{array}$ & 188.3 & 171.1 & 178.7 & 132.2 & $-1.4 *(-1.6 ;-1.2)$ & 1986-1996 & $-0.6(-1.2 ; 0.1)$ & $1996-2011$ & $-1.8 *(-2.2 ;-1.5)$ \\
\hline $\begin{array}{l}\text { Prostate } \\
\text { cancer }\end{array}$ & 16.07 & 20.7 & 14.8 & 13.8 & $-0.6 *(-1.1 ;-0.2)$ & 1986-1996 & $1.00(-0.9 ; 2.8)$ & 1996-2011 & $-1.4 *(-2.2 ;-0.6)$ \\
\hline \multicolumn{10}{|l|}{$\begin{array}{l}\text { Female } \\
\text { population }\end{array}$} \\
\hline $\begin{array}{l}\text { Overall } \\
\text { cancer }\end{array}$ & 133.6 & 146.3 & 105.6 & 90.3 & $-0.8 *(-1.0 ;-0.6)$ & 1986-1996 & $0.1(-0.7 ; 0.8)$ & $1996-2011$ & $-1.3 *(-1.7 ;-0.9)$ \\
\hline Breast cancer & 25.22 & 31.52 & 21.1 & 20.4 & $-0.6 *(-1.1 ;-0.2)$ & 1986-1996 & $1.4 *(0.2 ; 2.7)$ & $1996-2011$ & $-1.7 *(-2.3 ;-1.1)$ \\
\hline
\end{tabular}

95\% Cl: 95\% confidence interval.

* The annual percent change is significantly different to zero at alpha $=0.05$.

Table 2 shows the net change in terms of crude mortality rates and total number of deaths from cancer, which can be partitioned into fractions (\%) attributable to mortality risk variations and demographic changes (population size and age structure). As shown, there was a positive crude mortality rate net change for overall cancer in women (increment of 12.7 deaths/100,000: 9.51\%), breast (6.3 deaths/100,000: 24.97\%) and prostate cancers (4.6 deaths/100,000: 28.76\%) through the period 19862011 (Table 2). Main changes were due to modifications in demographic factors in women (Figure 3). However, male cancer crude mortality rate showed a $9.15 \%$ decrease, with the highest proportion of variation attributable to changes in the risk of death from this cause (Table 2, Figure 3). Overall, regarding the four sub-periods analyzed, the net crude mortality rate change (Table 2) increased up until 1996 and subsequently decreased.

The risk component of total variation of crude mortality rate only showed a positive difference in breast cancer mortality (Figure 3). In fact, in 2011 the fraction attributable to risk was 5.22\% larger than in 1986. It should be noted that this increased risk results from a balance of periods with increased mortality, followed by periods of decreased mortality rates for this cancer (after 1996), as shown in Table 2. Regarding prostate cancer, death risk showed a drop of 7.13\% in the 1986-2011 period (Table 2).

In terms of the absolute number of deaths (Table 2), the differences were positive across the whole period of study (1986 to 2011) for all cases. Thus, there was an increase of 769 deaths (net change) from overall cancer in women, of which 603.7 (34.76\%) were due to changes (i.e. an increase) in population size, 549.9 (31.66\%) were due to changes in age structure, and $384.6(22.14 \%)$ due to the decreased risk. In males, there was a 406 net increase of deaths from cancer of which $28.93 \%, 26.39 \%$ and $19.78 \%$ were attributable to the decreased risk, an increase in the size of the population and structural changes in the population, respectively. However, although the number of deaths by cancer was higher in 2011 than in 1986, the net percentage of variation tends to decrease by 2011 (Table 2).

Considering demographic factors, there was an important increase in changes attributable to age structure variations since 1996, mainly in prostate cancer rates (an increment of 12.82\% in the 


\section{Figure 1}

Age-standardized (world population) mortality rate trends for women and men. Córdoba province, Argentina, 1986-2011: Joinpoint analysis for overall cancer mortality rates.
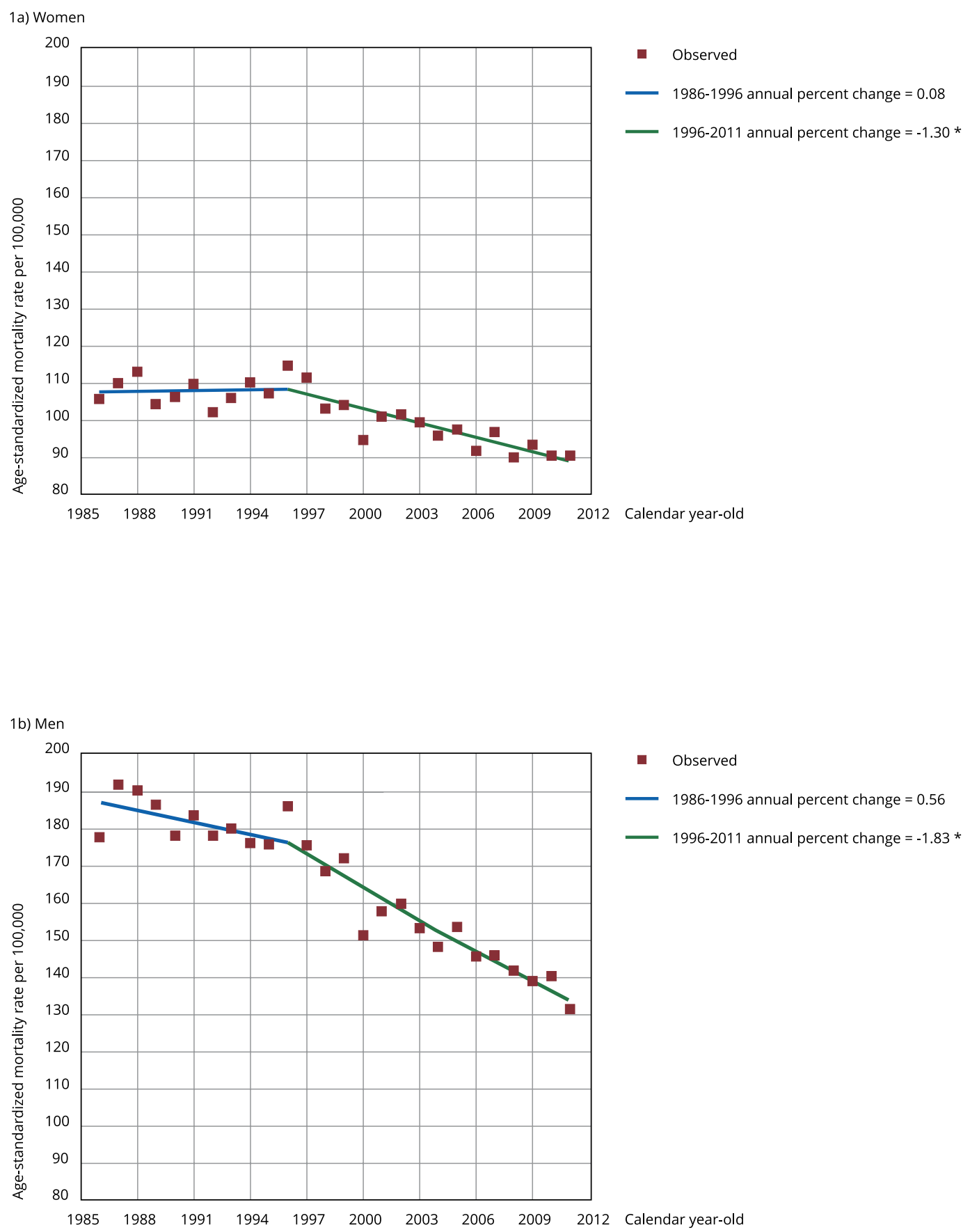

* The annual percent change is significantly different to zero at alpha $=0.05$. 
Figure 2

Age-standardized (world population) mortality rate trends for Córdoba province, Argentina, 1986-2011: joinpoint analysis for breast and prostate cancer mortality rates.

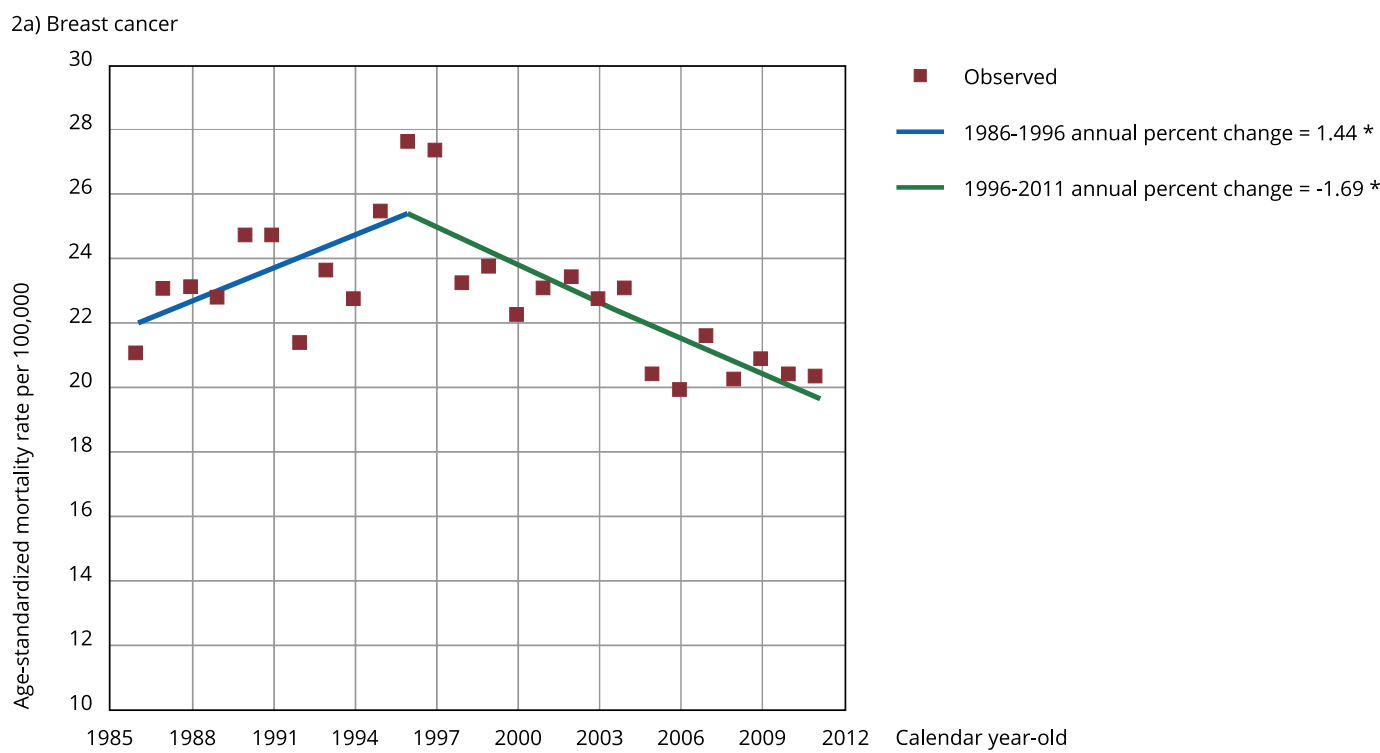

2a) Prostate cancer

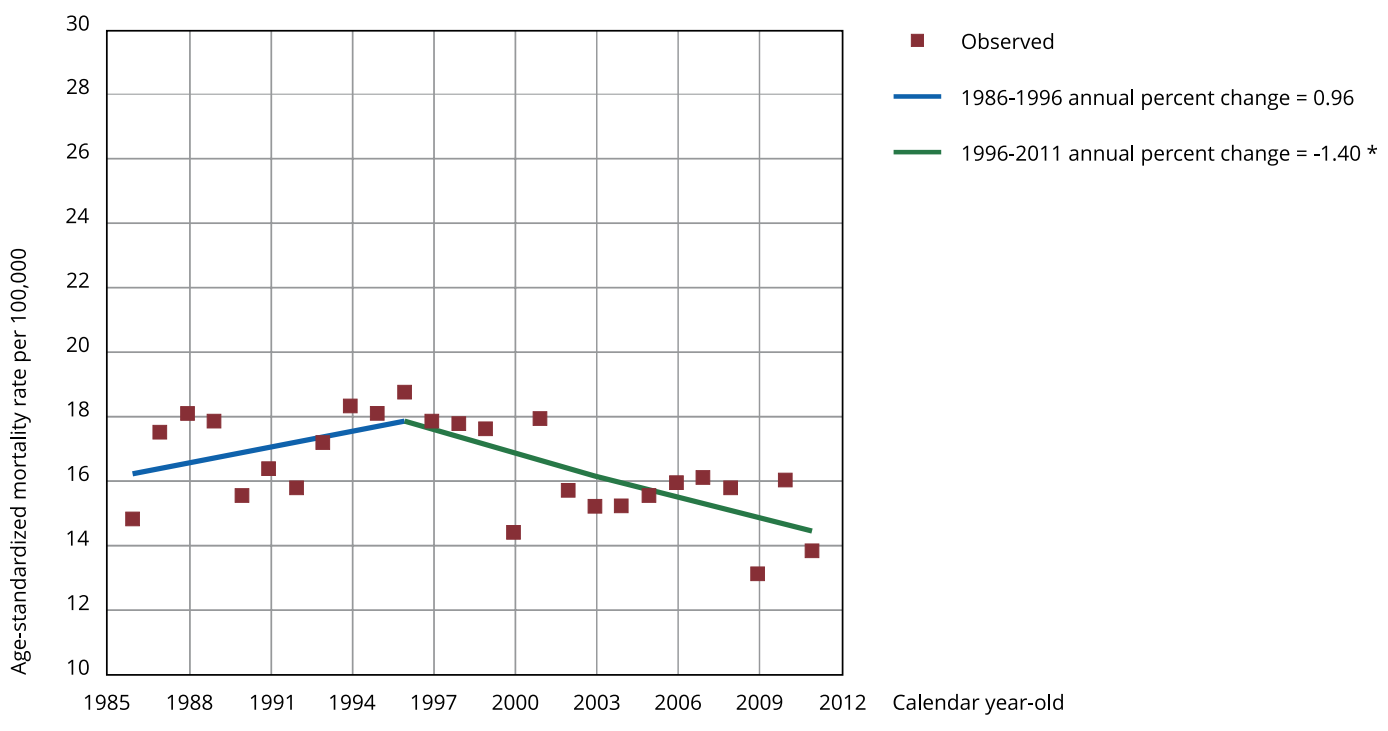

* The annual percent change is significantly different to zero at alpha $=0.05$. 


\section{Table 2}

Mortality risk variations and demographic changes relating to crude mortality rates and total number of deaths due to overall cancer, breast and prostate cancers. Córdoba province, Argentina, 1986-2011.

\begin{tabular}{|c|c|c|c|c|c|c|c|}
\hline \multirow[t]{2}{*}{ Period } & \multicolumn{3}{|c|}{ Change in crude rate } & \multicolumn{4}{|c|}{ Change in number of deaths } \\
\hline & $\begin{array}{c}\text { Risk } \\
\text { variations } \\
(\%)\end{array}$ & $\begin{array}{c}\text { Demographic } \\
\text { factors } \\
(\%)\end{array}$ & $\begin{array}{c}\text { Net } \\
\text { change } \\
(\%)\end{array}$ & $\begin{array}{c}\text { Risk } \\
\text { variations } \\
(\%)\end{array}$ & $\begin{array}{c}\text { Age } \\
\text { structure } \\
(\%)\end{array}$ & $\begin{array}{l}\text { Population } \\
\text { size } \\
(\%)\end{array}$ & $\begin{array}{c}\text { Net } \\
\text { change } \\
(\%)\end{array}$ \\
\hline \multicolumn{8}{|c|}{$\begin{array}{l}\text { Overall cancer mortality } \\
\text { (female population) }\end{array}$} \\
\hline 1986-1991 & $3.4(2.54)$ & $8.8(6.61)$ & $12.2(9.15)$ & $44.1(2.54)$ & $114.8(6.61)$ & 170.1 (9.79) & 329.0 (18.94) \\
\hline 1991-1996 & $7.8(5.34)$ & $6.4(4.36)$ & $14.1(9.70)$ & $110.3(5.34)$ & $90.2(4.36)$ & $76.5(3.71)$ & $277.0(13.41)$ \\
\hline $1996-2001$ & $-21.2(-13.23)$ & $14.3(8.97)$ & $-6.8(-4.27)$ & $-310.0(-13.23)$ & $210.1(8.97)$ & $171.9(7.34)$ & $72.0(3.07)$ \\
\hline $2001-2011$ & $-18.5(-12.09)$ & $11.7(7.63)$ & $-6.8(-4.47)$ & $-292.1(-12.09)$ & $184.2(7.63)$ & $198.8(8.23)$ & $91.0(3.77)$ \\
\hline $1986-2011$ & $-29.6(-22.14)$ & $42.3(31.66)$ & $12.7(9.51)$ & $-384.6(-22.14)$ & $549.9(31.66)$ & $603.7(34.76)$ & $769.0(44.27)$ \\
\hline \multicolumn{8}{|c|}{$\begin{array}{l}\text { Overall cancer mortality } \\
\text { (male population) }\end{array}$} \\
\hline 1986-1991 & $6.5(3.47)$ & $6.3(3.37)$ & $12.9(6.83)$ & $81.6(3.47)$ & $79.3(3.37)$ & $199.1(8.45)$ & $360.0(12.29)$ \\
\hline 1991-1996 & $1.7(0.86)$ & $5.1(2.53)$ & $6.8(3.39)$ & $23.3(0.86)$ & $68.7(2.53)$ & $87.0(3.20)$ & $179.0(6.59)$ \\
\hline $1996-2001$ & $-31.6(-15.17)$ & $10.9(5.26)$ & $-20.6(-9.91)$ & $-439.1(-15.17)$ & $152.2(5.26)$ & $183.9(6.35)$ & $-103.0(-3.56)$ \\
\hline $2001-2011$ & $-32.5(-17.35)$ & $16.2(8.64)$ & $-16.3(-8.70)$ & $-484.1(-17.35)$ & $241.2(8.64)$ & $212.9(7.63)$ & $-30.0(-1.07)$ \\
\hline $1986-2011$ & $-54.5(-28.93)$ & $37.2(19.78)$ & $-17.2(-9.15)$ & $-681.4(-28.93)$ & $465.8(19.78)$ & $621.9(26.39)$ & $406.0(17.24)$ \\
\hline \multicolumn{8}{|c|}{ Breast cancer mortality } \\
\hline 1986-1991 & $4.4(17.34)$ & $1.2(4.64)$ & $5.5(21.98)$ & $56.9(17.34)$ & $15.2(4.64)$ & $35.9(10.94)$ & $108.0(32.93)$ \\
\hline 1991-1996 & $4.2(13.67)$ & $0.9(2.80)$ & $5.1(16.48)$ & $59.6(13.67)$ & $12.2(2.80)$ & $17.1(3.93)$ & $89.0(20.41)$ \\
\hline $1996-2001$ & $-5.0(-13.93)$ & $2.5(6.98)$ & $-2.5(-6.94)$ & $-73.1(-13.93)$ & $36.7(6.98)$ & $37.4(7.13)$ & $1.0(0.19)$ \\
\hline $2001-2011$ & $-5.0(-13.47)$ & $2.7(7.99)$ & $-1.8(-5.48)$ & $-70.9(-13.47)$ & $42.0(7.99)$ & $42.8(8.15)$ & $14.0(2.66)$ \\
\hline $1986-2011$ & $1.3(5.22)$ & $5.0(19.75)$ & $6.3(24.97)$ & $17.1(5.22)$ & $64.8(19.75)$ & $130.1(39.66)$ & $212.0(64.63)$ \\
\hline \multicolumn{8}{|c|}{ Prostate cancer mortality } \\
\hline 1986-1991 & $1.8(11.01)$ & $1.0(6.09)$ & $2.7(17.10)$ & $22.1(11.01)$ & $12.2(6.09)$ & $18.6(9.27)$ & $53.0(26.37)$ \\
\hline 1991-1996 & $2.8(14.25)$ & $0.8(4.13)$ & $3.5(18.38)$ & $36.2(14.25)$ & $10.5(4.13)$ & $9.3(3.67)$ & $56.0(22.05)$ \\
\hline $1996-2001$ & $-0.7(-3.00)$ & $1.9(8.77)$ & $1.3(5.77)$ & $-9.3(-3.00)$ & $27.2(8.77)$ & $23.1(7.46)$ & $41.0(13.23)$ \\
\hline $2001-2011$ & $-5.9(-25.00)$ & $3.0(12.82)$ & $-2.9(-12.18)$ & $-87.7(-25.00)$ & $45.0(12.82)$ & $25.7(7.34)$ & $-17.0(-4.84)$ \\
\hline $1986-2011$ & $-1.1(-7.13)$ & $5.8(35.87)$ & $4.6(28.76)$ & $-14.3(-7.13)$ & $72.1(35.89)$ & $75.2(37.41)$ & $133.0(66.17)$ \\
\hline
\end{tabular}

number of deaths by this cause through the period 2001-2011), while changes in population size meant a continuous increase in the number of deaths since 1991 (Table 2).

Breast and prostate cancer crude mortality rate did not follow similar patterns of change due to risk, neither between them nor in comparison with overall cancer for females and males, respectively (Table 2).

\section{Discussion}

Favorable age-standardized mortality rates trends were observed in overall, breast and prostate cancers in the 1986-2011 period in Córdoba province, with a decreasing shift of rates in 1996. For breast cancer, this change was preceded by a significant increase of age-standardized mortality rates between 1986 and 1996. In terms of crude mortality rate, there was an increment for overall cancer (female), breast and prostate cancers throughout the 25 year period analyzed. This was primarily due to demographic changes which can be interpreted in our context as attributed to population aging. 
Analysis of the change (\%) in overall, breast and prostate cancer crude mortality rate (deaths per 100,000) attributable to demographic and risk factors for the population of Córdoba province, Argentina, between 1986 and 2011.

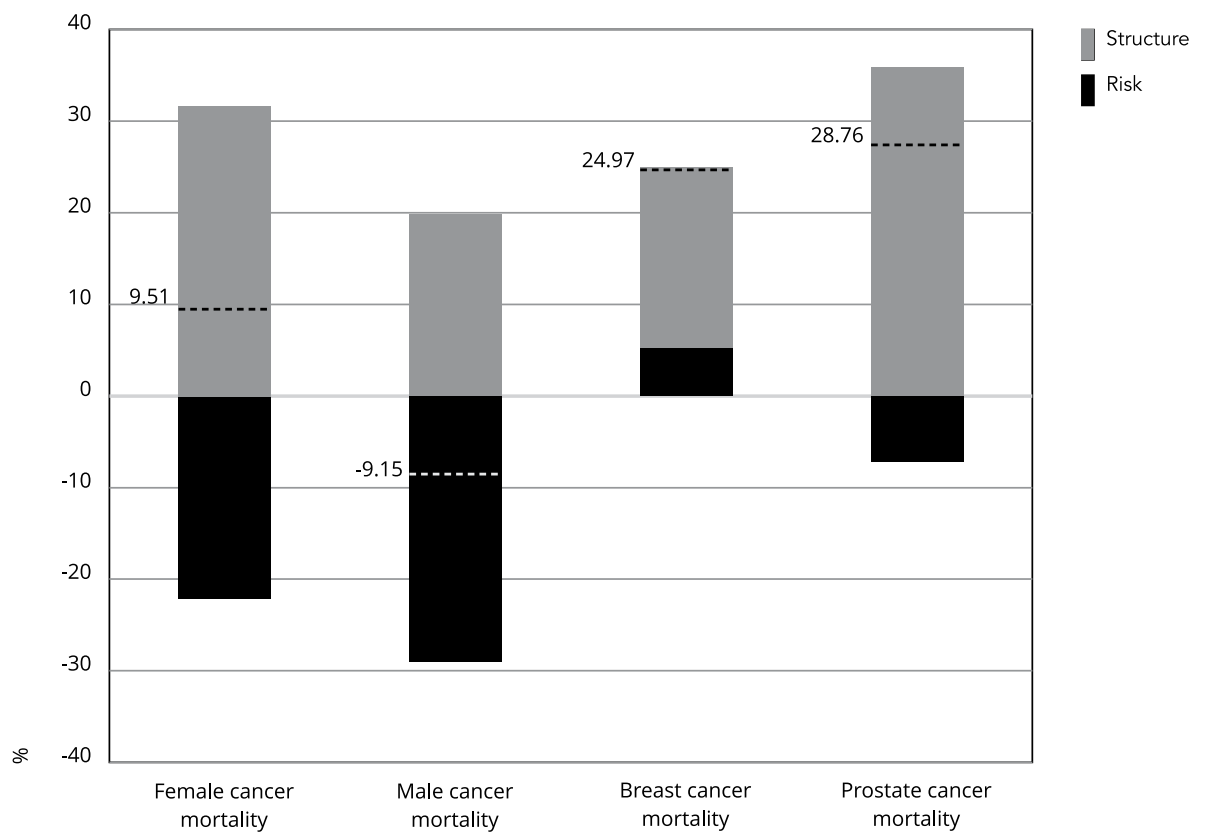

Note: the dotted line indicates the end point of the sum of the two components (i.e. net change in crude mortality rate).

Overall male crude mortality rate showed a decreased net change, mostly due to mortality risk variations. Differential patterns of risk of death were found for breast and prostate cancer.

Although the region of Latin America has followed the global trend of an aging population, the populations of Uruguay and Argentina are differentiated by an age structure that is comparable to developed countries, mainly determined by an early and continuous decrease in fertility rates to very low levels. This trend could have a pronounced effect on the epidemiological profile of this population, considering that the increment of elderly population size over time implies a higher number of people at risk of dying from cancer 15 . However, the fact that cancer has become more common as a cause of death compared with other non-communicable diseases does not necessarily mean that the risk of dying from degenerative diseases has increased 16. This points to the importance in differentiating the contribution of changes in demographic factors and the age-independent "risk" of dying from cancer on the observed trends.

It is noteworthy that one of the highest cancer mortality rates within the Americas has been observed in Argentina 17,18, reporting relatively high female breast cancer mortality as well 19. This scenario is also present in Córdoba, a province that is among the most populous in Argentina (preceded only by Buenos Aires) and has been considered representative of the country as a whole because they both have similar population spatial distributions 20. From classic demographic and epidemiological transition approaches, Argentina is considered to be in an advanced stage of transition. However, to elucidate mortality risk patterns it is necessary to go beyond the classical transition theories, which have been criticized for their overemphasis on mortality without taking into consideration the changing causes of patterns of illness 1,3. Therefore, diverse viewpoints are considered below.

Net changes of number of deaths by cancer found in our study are in agreement with the International Agency for Research on Cancer (IARC) prognosis 21. As an exception, a decrease in the number 
of deaths was only observed for men over the last decade. Otherwise, the decreasing trends in the magnitude of net change of deaths towards 2011 might be attributable to the reduction or delay in deaths caused by chronic diseases, due to the progressive increase in survival rates among the elderly. This late stage of mortality transition has recently been added by some authors 7 .

After age adjustment, a decreasing risk of death from cancer was found in Córdoba, which is similar to most Latin American countries in recent decades 19, including Argentina 17. Previous results from age-period-cohort analyses of cancer mortality up to 2006 agreed with our findings $22,23,24,25$. Our study showed a significant and consistent shift of cancer age-standardized mortality rates trends around 1996. Downward mortality trends since the mid-1990s for total female cancer 24, and for breast and prostate cancers 19,24,25 have been reported previously in Argentina. Moreover, it is interesting to note that the Superintendence of Health Services (the Argentine center which controls the agents of the National System of Health Insurance) was created in 199626 and that the self-management of public hospitals and deregulation of the health insurance system has been promoted in Argentina since 1990 27. In view of the health care transition approach 7,8, these interventions may influence the access to medical care systems or changes in public health practices, which may impact on mortality rates, although the results of a decentralized health policy in Córdoba have been questioned.

A significant upward age-standardized mortality rates trend was only observed for breast cancer up until 1996 (decreasing thereafter), and was accompanied by a similar change in crude mortality rate attributable to risk. Therefore changes in exposition to recognized risk factors for breast cancer, such as dietary habits and other lifestyle factors 18,28,29, as well as changes in breastfeeding and reproductive habits 19,30 may underlie this temporal pattern. Besides, it is important to mention the creation of two sexual and reproductive health programs (at provincial and national levels, in 1996 and 2002, respectively). This may have contributed to the observed favorable change in the later period, since these programs promote women's access to health care 27. In developed countries, improvements in breast cancer mortality were attributable to advancements in therapy, including the widespread use of tamoxifen, although some importance has been given to mammographic screening 18. In Argentina, a national survey showed a rise in the proportion of women over forty years of age who had mammograms (42.5\% in 2005 and $65.6 \%$ in 2013) 31 , which might imply an improvement in the early detection of breast cancer in recent years.

Since 1996, prostate cancer age-standardized mortality rate has also clearly been declining in Córdoba. A systematic screening in men over 50 years old through rectal examinations and prostatespecific antigen (PSA) testing has been implemented in Argentina since mid-1990s 25. Although this implies earlier diagnosis of the disease, it has been suggested that the downward mortality trend is mainly attributable to an increase in survival rates due to improvements in the treatment of the disease 18,19. In fact, in Argentina PSA testing never became widespread, although recent improvements in treatments (transurethral prostatectomy, hormone and radiotherapy) can be observed 25. In our opinion, all these factors might explain the observed decrease in rates attributable to risk of death for prostate cancer.

Breast and prostate cancer mortality did not show similar patterns of change in relation to risk, even when these are typically hormone-dependent tumors and have remarkable underlying biological similarities 32 . This is probably related to other social or cultural gender-specific differences. Furthermore, both cancers follow a differential pattern of mortality risk with respect to male and female total cancer patterns, especially before 1996. This could be linked to changes in the prevalence of specific exposure factors associated to these hormone-dependent cancers (e.g. fertility-related factors in breast cancer). Also, the impact of advancements on control of other cancer sites on total cancer mortality (such as tobacco control in lung cancer, uterine cancer screening programs) could clarify these patterns.

In spite of the positive net change of number of deaths for prostate cancer in Córdoba between 1986 and 2011, the overall cancer mortality in men showed a decrease, both in terms of age-adjusted and crude rates. Given that lung cancer is the primary cause of death by malignant neoplasms in men in Córdoba 17, it is possible to argue that this cancer site is indeed the main reason for overall cancer mortality trends in males, reflecting the decreasing smoking prevalence observed in recent 
decades in Argentina 31 . This could explain why the overall change in male cancer crude mortality rate (1986-2011) was mainly attributable to risk of death in our results.

In our opinion, the patterns of variation in crude mortality rate and number of cancer deaths observed are consistent with the proportional increase of elderly people (population aging) and the biology of cancer sites considered here. In fact, cancer incidence should be considered as an exponential function of age 15. In Latin America, due to the "feminization" of aging 13, it is expected that age structure and size population variations may prevail as determinants of the changes in female cancer mortality from 1986 to 2011, compared with overall cancer rates in the male population. Even so, higher net changes due to variations in age structure were registered in prostate cancer mortality. This fact is consistent with the natural history of this disease considering the age of onset at which it starts, largely in people over 50 years old 33 (vs. 35 years for breast cancer) 34 . Hence, even when there are more elderly women than men, elderly people are more likely to become ill (or die) from prostate cancer. In fact, Argentina has prostate incidence rates around two times higher than breast cancer rates in people aged 75 or older 21 .

The limitations of our work need to be considered. An analysis of risk trends was conducted using two different methodologies, which do not reproduce exactly the same results. Minor differences could be attributable to the use of a world population as reference for the standardization process in the Joinpoint analysis, while in the Bashir \& Estève 10 analysis the real age structure of the Córdoba population was preserved. In our opinion, these analyses are indeed complementary. Another limitation is the shortage of cancer statistics, as well as morbidity rates, to complete the cancer burden analysis in Córdoba. Created in 2004, the Provincial Tumor Registry of Córdoba does not provide enough longitudinal data to perform similar analyses of incidence trends. Regarding mortality data, Argentina is considered to have an adequate system 17 . Although a 25 year period could be considered not enough to draw conclusions about underlying epidemiological and demographic changes, our research is - as far as we know - the first one to integrate both approaches in the study of cancer mortality in the Latin America region.

Before concluding, it is worth giving some consideration to data quality of cause of death over the 25-year period covered by the present study. Firstly, comparison of cause of death data over time should be undertaken with caution, considering the implications of changes introduced in the ICD 35 . The ICD-10 was adopted in 1997 by the Statistical Health System of Argentina 5. The Pan American Health Organization (PAHO) highlighted that there are modifications from ICD-9 to ICD-10 regarding categories 36. Although some studies found a slight impact of coding changes between the 9th and 10 th revisions, minor variations in the category of malignancies were reported 37,38. In addition, comparability of findings on causes of mortality could be affected by death registration coverage and differences in coding practices 35 or legal and institutional frameworks for mortality reporting 39. In general, there is an agreement on the completeness, timeliness and availability of data on deaths in Argentina, with death registration coverage of $90 \%$ or more 40,41 . Other aspects, such as medical culture or institutional practices related to the death registration process, have been studied very little in this country.

To conclude, despite the favorable trends in cancer mortality observed in Córdoba since the mid1990s, there are two points to highlight: (a) Argentina is still among the countries with the highest aged-standerdized mortality rate for prostate and breast cancers, and (b) the observed influence of population aging on cancer mortality trends in the Córdoba population reinforces the challenge to control cancer in populations with an increasingly aged demographic structure, especially considering that the process in Latin America occurs in a context of social inequality which affects access to health care. 


\section{Contributors}

S. A. Pou contributed to the conception and design of this study, the analysis and interpretation of data for the research, and drafting the paper. N. Tumas and M. P. Díaz contributed to the conception and design of this study, the analysis and interpretation of data for the research, and drafting the paper. J. Becaria Coquet, C. Niclis and M. D. Román contributed to the interpretation of data for the research and the critical revision for important intellectual content of the manuscript. The manuscript has been seen and approved by the all the authors, who agrees to be accountable for all aspects of the work.

\section{Acknowledgments}

We are particularly grateful to the Córdoba Ministry of Health and the Argentinian Ministry of Health, for allowing us to use the mortality-database. We thank Gabriela Díaz Cortez, who carried out the language quality check of this manuscript. We would like to thank the National Scientific and Technical Research Council (CONICET) for N. Tumas, J. B. Coquet, C. Niclis and M. D. Román's fellowships. We thank Alberto R. Osella (PhD) for his assistance with the epidemiological design of this study. Further thanks to the Science and Technology National Agency [FONCyT PICT 2012-1019]; and the University of Córdoba [PID 1565/14].

\section{References}

1. McKeown RE. The epidemiologic transition: changing patterns of mortality and population dynamics. Am J Lifestyle Med 2009; 3(1 Suppl):19S$26 \mathrm{~S}$.

2. US Department of Health and Human Services; World Health Organization. Global health and aging. http://www.nia.nih.gov/sites/default/files/ global_health_and_aging.pdf (accessed on 01/ Jun/2015).

3. Caldwell JC. Population health in transition. Bull World Health Organ 2001; 79:159-60.

4. World Health Organization. Noncommunicable diseases. http://www.who.int/mediacentre/fact sheets/fs355/en (accessed on 30/Oct/2015).

5. Dirección de Estadísticas e Información de Salud, Ministerio de Salud de Argentina. Estadísticas vitales. Información básica - Año 2013. http://www. deis.gov.ar/Publicaciones/Archivos/Serie5Nro57. pdf (accessed on 30/Oct/2015).

6. Prince MJ, Wu F, Guo Y, Gutierrez Robledo LM, O'Donnell M, Sullivan R, et al. The burden of disease in older people and implications for health policy and practice. Lancet 2015; 385:549-62.
7. Caldwell JC. Demographers and the study of mortality: scope, perspectives, and theory. Ann N Y Acad Sci 2001; 954:19-34.

8. Caldwell JC. Health transition: the cultural, social and behavioural determinants of health in the Third World. Soc Sci Med 1993; 36:125-35.

9. Valls J, Clèries R, Gálvez J, Moreno V, Gispert R, Borràs JM, et al. RiskDiff: a web tool for the analysis of the difference due to risk and demographic factors for incidence or mortality data. BMC Public Health 2009; 9:473.

10. Bashir S, Estève J. Analysing the difference due to risk and demographic factors for incidence or mortality. Int J Epidemiol 2000; 29:878-84.

11. Instituto Nacional de Estadística y Censos. Censo Nacional de Población, Hogares y Viviendas 2010. http://www.censo2010.indec.gov.ar (accessed on 05/Jan/2016). 
12. Registro Provincial de Tumores de Córdoba, Ministerio de Salud de la Provincia de Córdoba. Informe sobre cáncer en la Provincia de Córdoba 2004-2009. Córdoba: Editorial de la Provincia de Córdoba; 2013.

13. Davidson PM, Digiacomo M, McGrath SJ. The feminization of aging: how will this impact on health outcomes and services? Health Care Women Int 2011; 32:1031-45.

14. Kim HJ, Fay MP, Feuer EJ, Midthune DN. Permutation tests for joinpoint regression with applications to cancer rates. Stat Med 2000; 19:335-51.

15. Napalkov NP. Cancer and demographic transition. Vopr Onkol 2004; 50:127-44.

16. Gage TB. Are modern environments really bad for us?: revisiting the demographic and epidemiologic transitions. Am J Phys Anthropol 2005; Suppl 41:96-117.

17. Abriata MG, Roques LF, Macías G, Loria D. Atlas de mortalidad por cáncer: Argentina 2007-2011. http://www.msal.gov.ar/inc/images/stories/do wnloads/publicaciones/29-Atlas-de-mortalida dopt.pdf (accessed on 17/Nov/2015).

18. Bosetti C, Malvezzi M, Chatenoud L, Negri E, Levi F, La Vecchia C. Trends in cancer mortality in the Americas, 1970-2000. Ann Oncol 2005; 16:489. 511.

19. Chatenoud L, Bertuccio P, Bosetti C, Malvezzi M, Levi F, Negri E, et al. Trends in mortality from major cancers in the Americas: 1980-2010. Ann Oncol 2014; 25:1843-53.

20. Díaz MP, Osella AR, Aballay LR, Muñoz SE, Lantieri MJ, Butinof M, et al. Cancer incidence pattern in Cordoba, Argentina. Eur J Cancer Prev 2009; 18:259-66

21. Ferlay J, Soerjomataram I, Ervik M, Dikshit R, Eser S, Mathers C, et al. GLOBOCAN 2012 v. 1.0, Cancer Incidence and Mortality Worldwide: IARC CancerBase No. 11. http://globocan.iarc.fr (accessed on 05/Jan/2015).

22. Pou SA, Osella AR, Eynard AR, Diaz M P. Cancer mortality in Córdoba, Argentina, 1986-2006: an age-period-cohort analysis. Tumori 2010; 96: 202-12.

23. Pou SA, Osella AR, Diaz MP. Bladder cancer mortality trends and patterns in Córdoba, Argentina (1986-2006). Cancer Causes Control 2011; 22:407-15.

24. Niclis C, Del Pilar Díaz M, La Vecchia C. Breast cancer mortality trends and patterns in Córdoba, Argentina in the period 1986-2006. Eur J Cancer Prev 2010; 19:94-9.

25. Niclis C, Pou SA, Bengió RH, Osella AR, Díaz MP. Prostate cancer mortality trends in Argentina 1986-2006: an age-period-cohort and joinpoint analysis. Cad Saúde Pública 2011; 27:123-30.

26. Belló M, Becerril-Montekio VM. Sistema de salud de Argentina. Salud Pública Méx 2011; 53 Suppl 2:s96-s108.

27. Tumas N, Niclis C, Osella AR, Díaz MP, Carbonetti A. Tendencias de mortalidad por cáncer de mama en Córdoba, Argentina, 1986-2011: algunas interpretaciones sociohistóricas. Rev Panam Salud Pública 2015; 37:330-6.
28. Tumas N, Niclis C, Aballay LR, Osella AR, Díaz MP. Traditional dietary pattern of South America is linked to breast cancer: an ongoing case-control study in Argentina. Eur J Nutr 2014; 53:557-66.

29. Aballay LR, Eynard AR, Díaz MP, Navarro A, Muñoz SE. Overweight and obesity: a review of their relationship to metabolic syndrome, cardiovascular disease, and cancer in South America. Nutr Rev 2013; 71:168-79.

30. Kruk J. Lifestyle components and primary breast cancer prevention. Asian Pac J Cancer Prev 2014; 15:10543-55.

31. Instituto Nacional de Estadística y Censos, Ministerio de Salud de la Nación. 3a Encuesta Nacional de Factores de Riesgo para Enfermedades no Trasmisibles. Presentación de los principales resultados. http://www.msal.gov.ar/images/stories/ publicaciones/pdf/11.09.2014-tercer-encuentronacional-factores-riesgo.pdf (accessed on 15/ Nov/2015).

32. Risbridger GP, Davis ID, Birrell SN, Tilley WD. Breast and prostate cancer: more similar than different. Nat Rev Cancer 2010; 10:205-12.

33. Fung C, Dale W, Mohile SG. Prostate cancer in the elderly patient. J Clin Oncol 2014; 32:2523-30

34. Han W, Kang SY; Korean Breast Cancer Society. Relationship between age at diagnosis and outcome of premenopausal breast cancer: age less than 35 years is a reasonable cut-off for defining young age-onset breast cancer. Breast Cancer Res Treat 2010; 119:193-200.

35. World Health Organization. WHO mortality database. http://www.who.int/healthinfo/cod/en/ print.html (accessed on 15/Apr/2016).

36. Organización Panamericana de la Salud. Revisión de la Clasificación Internacional de Enfermedades (CIE-9 y CIE-10): impacto en las estadísticas de salud. Boletín Epidemiológico 1996; 17:1-4.

37. Janssen F, Kunst AE. ICD coding changes and discontinuities in trends in cause-specific mortality in six European countries, 1950-99. Bull World Health Organ 2004; 82:904-13.

38. Ruiz M, Cirera Suárez L, Pérez G, Borrell C, Audica C, Moreno C, et al. Comparabilidad entre la novena y la décima revisión de la Clasificación Internacional de Enfermedades aplicada a la codificación de la causa de muerte en España. Gac Sanit 2002; 16:526-32.

39. Lozano R, Naghavi M, Foreman K, Lim S, Shibuya $\mathrm{K}$, Aboyans V, et al. Global and regional mortality from 235 causes of death for 20 age groups in 1990 and 2010: a systematic analysis for the Global Burden of Disease Study 2010. Lancet 2012; 380:2095-128.

40. Ribotta BS. Hacia el seguimiento de los determinantes sociales de la salud: alcances y limitaciones de las estadísticas de defunción en la Argentina. Rev Fac Nac Salud Pública 2013; 31 Suppl 1:S149_ S59.

41. United Nations Statistics Division. Coverage of birth and death registration. http://unstats.un.org/ unsd/demographic/CRVS/CR_coverage.htm (accessed on 15/Apr/2016). 


\section{Resumen}

El mundo enfrenta el fenómeno del envejecimiento poblacional, con grandes contingentes de individuos afectados por enfermedades crónicas. Entre los países de América Latina, Argentina ya alcanzó un nivel avanzado en la transición demográfica y presenta una tasa relativamente alta de mortalidad por cáncer. El estudio tuvo como objetivos: examinar las tendencias en la mortalidad por cáncer en la provincia de Córdoba, Argentina, entre 1986 y 2011, y analizar las diferencias atribuibles a variaciones de riesgo y cambios demográficos. Para estimar la variación porcentual anual, se elaboraron modelos de series longitudinales de la tasa de mortalidad estandarizada por edad para todos los cánceres y, específicamente, para mama y próstata utilizando regresión Joinpoint. Se utilizó el método de Bashir es Estève para dividir la variación de la tasa bruta de mortalidad en tres componentes: riesgo de mortalidad, estructura etaria poblacional y tamaño de la población. Se observó una tendencia decreciente en la tasa de mortalidad estandarizada por edad por cáncer (variación porcentual annual 1986-2011: -1,4; IC95\%: - 1,6; - 1,2 en hombres; -0, 8; IC95\%: - 1,0; -0,6 en mujeres), con un cambio significativo en 1996. Las tasas brutas de mortalidad aumentaron para todos los cánceres en mujeres, y de mama y próstata, lo cual fue atribuible principalmente a cambios demográficos. Inversamente, la tasa bruta de mortalidad para todos los cánceres en hombres mostró una caída de 9,15\%, influenciada básicamente por el riesgo de mortalidad. A pesar de las tendencias favorables en la tasa de mortalidad estandarizada por edad, la influencia del envejecimiento poblacional refuerza el desafío del control de cáncer en poblaciones con una estructura etaria cada vez más envejecida.

Neoplasias; Costo de Enfermedad;

Envejecimiento de la Población

\section{Resumo}

O mundo enfrenta o fenômeno do envelhecimento populacional, com grandes contingentes de individuos afetados por doenças crônicas. Entre os países da América Latina, a Argentina já atingiu um patamar avançado na transição demográfica e apresenta uma taxa relativamente alta de mortalidade por câncer. O estudo teve como objetivos, examinar as tendências na mortalidade por câncer na província de Córdoba, Argentina, entre 1986 e 2011. $e$ analisar as diferenças atribuíveis a variações de risco e mudanças demográficas. Para estimar a variação percentual anual, a regressão Joinpoint foi utilizada para elaborar modelos de séries longitudinais da taxa de mortalidade padronizada por idade para todos os cânceres e especificamente para mama e próstata. Foi utilizado o método de Bashir es Estève para dividir a variação da taxa bruta de mortalidade em três componentes: risco de mortalidade, estrutura etária populacional e tamanho da população. Observou-se uma tendência decrescente na taxa de mortalidade padronizada por idade por câncer (variação percentual annual 1986-2011: -1,4; IC95\%: - 1,6; - 1,2 em homens; -0.8, IC95\%: - 1,0; -0.6 em mulheres), com um deslocamento significativo em 1996. As taxas brutas de mortalidade aumentaram para todos os cânceres em mulheres, e de mama e próstata, atribuiveis principalmente a mudanças demográficas. Inversamente, a taxa bruta de mortalidade para todos os cânceres em homens mostrou uma queda de 9,15\%, influenciada basicamente pelo risco de mortalidade. Apesar de tendências favoráveis na taxa de mortalidade padronizada por idade, a influência do envelhecimento populacional reforça o desafio do controle de câncer em populações com estrutura etária cada vez mais envelhecida.

Neoplasias; Efeitos Psicossociais

Envelhecimento da População
Submitted on $31 / \mathrm{Jan} / 2016$

Final version resubmitted on 25/Apr/2016

Approved on 02/May/2016 